\author{
Journal of International Business Research and \\ Marketing \\ Volume 4, Issue 2, 2019 \\ journal homepage: www.researchleap.com
}

\title{
Do Earnings Management Leads to Sub-optimal Investments by Firms? Empirical Evidence from the Textile Sector of Pakistan
}

\author{
${ }^{1}$ Umair Saeed Bhutta, ${ }^{2}$ Zhang Youtang, ${ }^{3}$ Ali Raza \\ School of Management, Wuhan University of Technology, Wuhan PRC
}

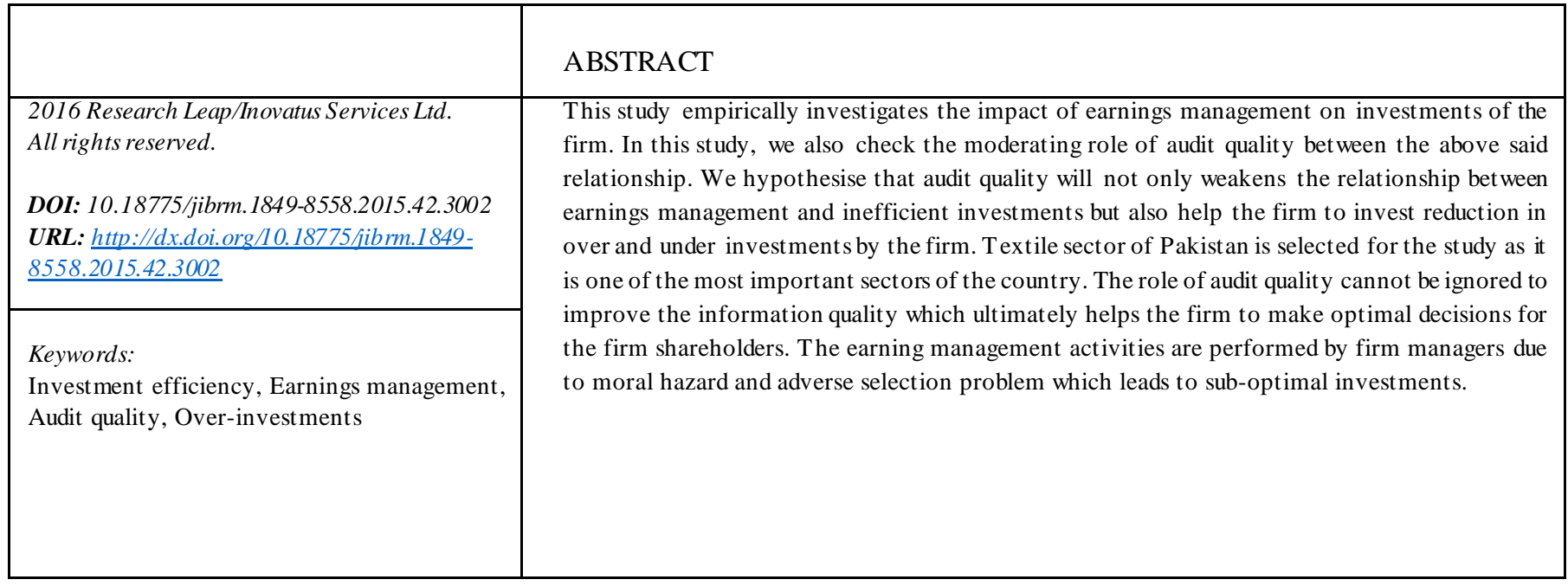

\section{Introduction}

The Earning Management (hereafter EM) activities are a common practice in the corporate world and researchers are drawing their attention to this phenomenon for the last two decades or so. The stakeholders and regulators are curious about EM activities and they want to know how it impacts the quality of company level activities and managers performance. $\mathrm{EM}$ is the way to alter the operating results of the firm by the inside managers to mislead the outside stakeholders (Healy and Wahlen, 1999). In the neoclas sical scenario, firms invest their money in capital intensive projects until the value of marginal benefits is equal or more than the marginal cost of the project (Modigliani and Miller, 1958). The concept of investing until an increase in the total value of the company is not fully implemented in the real-world scenario due to market frictions. The firms due to transaction and taxcosts invest inappropriately and at times invest more than the requirement of the firm or forgo some of the positive NPV projects (Myers, 1984, Fazzari et al., 1988). The quality of information impacts the investment efficiency of the firm and if there is a huge gap between information level of firm managers and shareholders than it can impact negatively on the investment efficiency of the firm (Bushman and Smith, 2001). The reduction in EM activities reduce the chances for the firm to indulge in sub-optimal investments and the problem of moral hazard and adverse selection can be reduced (Biddle et al., 2009, Chen et al., 2011, McNichols and Stubben, 2008). The quality of auditors has a significant impact on the financial statements quality of the firms and due to recent financial frauds in the corporate world, the auditors' role is under scrutiny (Romanus et al., 2008). To ensure and to make credibility of financial statements the role of auditors is very critical. The excellent quality auditors reduce information asymmetry and reduce the friction between different stakeholders of the firm (Newman et al., 2005).

Our research is a significant contribution to the literature as it will give a new dimension to research area about firm investment and EM. As per our knowledge, there is scare research in the area and with the moderating effect of audit quality, the topic has not been researched much by the researchers. This research will be different from earlier research in this topic (Biddle et al., 2009, Cutillas Gomariz and Sánchez Ballesta, 2014, Houcine, 2013), in the sense that we are looking at the moderating effect of audit quality in relation to EM and investment efficiency. In our study, we used the unique dataset from the Textile sector of Pakistan. The research on this geographical location is not much and especially on the topic of EM, the researchers are not looking at its impact on different 
dimensions of firm performance. In this research, we analyze how Pakistan's firms are managing their earnings and how the moderating impact of audit has a positive influence on this relationship. Pakistan is a developing country and accounting regulations are evolving. Regulators are trying firms to discipline managers and to present financial affairs as it happens in the firm (WorldBank, 2018). The problem of EM exists in the country and managers are only earning for their benefits (Ilmas et al., 2018). The role of auditors is becoming essential and audit quality has its impact on the managerial decision making (Abid et al., 2018). This study is providing insight into how investment is affected by EM and how this impact is moderated by the quality of auditors.

The remainder of the paper is designed as follows. The following section of the study will discuss about the literature and hypothesis of the study. In section 3, the methodology will be explained followed by a discussion on results. The last section of this study is conclusion.

\section{Literature Review and Hypothesis}

Investment Efficiency and Earning Management

There are many studies that discuss how firms manage their earnings and their effect on the investment's decisions. The overinvestments problem occurs when the firm go for more investment than the growth opportunities which are available for it. The overinvestment problem is due to managers own interests than the interest of the firm. The underinvestment problem occurs when the firm makes less investment than the available opportunities for the firm. Cohen and Zarowen (2008), pointed out that firms which are involved in any EM activities i.e. real or accrual based earning management activities make sub-optimal investments. Biddle et al. (2009), conducted their research to check if accounting quality impacts the overinvestment or underinvestment. Their result concludes that as accounting information quality improves the firm make more consistent and efficient investments which makes them to not invest over or under an optimal level of investments. The investment by the firm become more consistent with a predicted level of investments as the firm involves in less earning management activities.

McNichols and Stubben (2008), presented their work in which they estimated that how earning management affects the investment decision made by the firm. In their study, they used a revenue-based earning management model to gauge the accrual quality of the firm. Their study highlighted that during the periods when firms are involved in misreporting of their accounting records make more investments than the optimal level. Their results also highlighted that after the era of misreporting the firms make more optimal investments and not make any over investment after that period. Shen et al. (2015), take the case of China to perform their study to check how EM effects the investment efficiency of the Chinese firms. They concluded that as the Chinese companies involve in EM they invest sub-optimally and make more capital investments. Their results are dependent on the extent that if they have considered outliers or not for their study, as the results not remain the same with and without the use of outliers for their study. Asma (2017), conduct her study by examining how four different characteristics of financial information have an impact on the investment efficiency of the firm. She points out that her research result suggests that characteristics of financial information like reliability and smoothness improve the quality of investments made by the firm. The other two factors namely conservatism and relevance have no impact on the quality of investments made by the firm. She conducted her study in the financial environment of Tunisia. So, the first hypothesis of the study is as follows:

- H1a: Earnings Management leads the firm to do overinvestments

- H1b: Earnings Management leads the firm to do underinvestments

Earning Management impact on Investment Efficiency in the presence of high Audit Quality

To check that how earning management activities impact investment efficiency in the presence of high audit quality I use interaction effect to see if in the presence of high audit quality which is proxied by the firm audit by Big4 or not impacts the investment efficiency. If overinvestment and underinvestment problems mitigated by good quality audits or still it aggravates the situation for the firm. It is more than to check that how earning management impacts investment efficiency of the firm like which is mentioned in other studies (Biddle et al., 2009, Cutillas Gomariz and Sánchez Ballesta, 2014, DeBoskey and Jiang, 2012, Cahan S. et al., 2006). The earning management is the activity which distorts the information and leads firm managers to make suboptimal investment decisions, in contrast, quality of auditors ensure firms to invest in high-quality investment opportunities, so it is expected as quality of audit improves it will minimize the adverse effect of EM on firm investment efficiency and improves a firm's investment efficiency.

- H2a: Moderating Role of Audit Quality weakens the relationship between EM and over-investments.

- H2b: Moderating Role of Audit Quality weakens the relationship between EM and under-investments.

\section{Research Design}

Data and Sample

The data for this study will be taken from textile firms listed in Pakistan Stock Exchange (PSX). The data is collected for the study for the period 2009-2016. Textile sector of the country is selected for the research as it is the leading manufacturing sector of the country and it shares in GDP of the country is highest (SBP, 2018). The results of the study provide insight 
into how investment activities are distorted due to EM and what are its consequences on future firm performances.

\section{Econometric Model and Variables}

Model Specifications

We used OLS regression with company and year fixed effects for the study. The continuous variables of the study will be winsorized at $1 \%$ and $99 \%$ to control for the outliers. The first model which is used to determine the relationship between earnings management and firm investment efficiency is as follows:

InvInef $f_{i, t}=\alpha_{0}+\beta_{1} E M_{i, t}+\beta_{2} A U Q_{i, t}+$

$+\sum_{i=1}^{n} \beta_{i}$ Controls $_{i, t}+\epsilon_{i, t}$

Where inineff is calculated by the process used by Biddle et al. (2009), EM is the proxy for earning management by the company for which two versions will be used. In the first version Accrual Earning Management (AEM) which is calculated through Stubben (2010) and Kaznik (2000) model will be used as the independent variable. The control variable in equation (1) refers to size, leverage, audit quality, financial distress, growth, operating cycle, debt, year and company dummy variables of the firm will be used (Biddle et al., 2009, Cutillas Gomariz and Sánchez Ballesta, 2014, Eisdorfer et al., 2013).

The second model of this study will determine how the audit quality of the firm has an impact on investment efficiency performance in the presence of EM. The interaction term between EM and AUQ will be generated to see the moderating effect of audit quality on the relationship between EM and investment efficiency. The equation 2 of the study is as follows:

$$
\begin{array}{r}
\text { InvIneff } f_{i, t}=\alpha_{0}+\beta_{1} E M_{i, t}+\beta_{2} A U Q_{i, t}+\beta_{3} E M * \\
A U Q_{i, t}+\sum_{i=1}^{n} \beta_{i} \text { Controls }_{i, t}+\epsilon_{i, t}
\end{array}
$$

In equation (2) of this study AUQ refers to audit quality of the firm, which is a dichotomous variable which take the value of 1 if a firm is audited by Big 4 audit companies in the audit industry otherwise its value will be 0 (Jere R. Francis and Wang, 2008). Big 4 audit firm is taken as superior audit quality and it enhances the credibility of firm reports which reduces the informational asymmetry between the firm and its shareholders. To check the moderating effect of firm audit quality on firm investment efficiency in the presence of EM, we used interaction term between EM and AUQ. The other variables in the equation (2) are the same as discussed in the equation (1) of the study.

\section{Variable Measures}

Dependent Variable

To ascertain investment efficiency, we employed the technique of Biddle et. al (2009). It is conceptually understandable that productive investment is one where a firm undertakes all positive NPV projects. The model to ascertain the investment efficiency of the firm uses the sales growth as the measure to see how much investment firm can carry out the growth opportunities. This model suggests that if there is no deviation between sales growth and investment of the firm than firm is making productive investment. The firm which overinvests from their expected level of investment are doing overinvestment and firms which are creating a lower level of investment than expected are involved in underinvestment. It shows managers are using their discretion to invest low or more than expected level and it hurts the objective of efficient investment by the firm.

Following the model, we expect that the firm will invest as per the growth opportunities of the firm. The deviation from this level will suggest that the firm is not creating productive investment. The inefficient investments are captured by the residuals of the model (3). The positive residuals show that overinvestment and negative residuals are of indication that the firm is making underinvestment. The model to capture investment efficiency is as follows:

Investment $_{i, t}=\alpha_{0}+\beta_{1}$ SalesGrowth $_{i, t-1}+\varepsilon_{i, t}$

Where investmenti,t is the investment in fixed assets and property plant and equipment made by the firm for the year. Sales growth is the rate of change in sales which is calculated as current sales minus last year's sales divided by previous year sales. The model will be estimated on the cross-sectionally basis for each year and for each industry. The absolute value of residuals will be taken and the high value of the residuals show that more investment inefficiency by the firm (Invineffi,t).

\section{Independent Variable}

Accrual Earning Management

The accrual earning management is the change in change in accrual management by the firm managers to get the desired results. Jones (1991) come up with his model to ascertain that if the firm is managing its earnings or not by means of accrual management. The managers of the firm try to manage earnings through accrual to get their desired results instead of giving the real picture of company performance to the stakeholders of the company. Dechow and Dichev (2000), modified the Jones model to reduce the noise in the calculations of the Jones model.

In this study, we are using accrual management model proposed by Stubben (2010) and Kasznik (1999). The Stubben model suggests that as sales of the company changes it must have an impact on the account receivables of the firm and if there is some deviation than it suggests that company is managing its accruals to manage its earnings. The model to determine accrual management is as follows:

$\Delta A R_{i, t}=\alpha_{0}+\beta_{1} \Delta$ Sales $_{i, t}+\varepsilon_{i, t}$ 
Where $\Delta A R_{i, t}$ is the change in account receivables and $\Delta$ Sales $_{i, t}$ changes in sales of the company. For each year, the residuals are calculated from equation 4 and residuals from equation 4 indicates AEM by the firm. All the variables in equation 4 are scaled by the lag of total assets to control the possibility of heteroskedasticity. The absolute value of residuals is taken, and the high value shows more earning management.

To check for the models of other discretionary accruals, I am using Kasznik model to check how AEM effects the firm investment efficiency. The model by Kasznik (1999), is based on the Jones (1991) model and it takes firm property plant and equipment (PPE) and CFO in consideration to check if the firm is engaged in accrual earning management or not. The regression equation for calculating $\mathrm{AEM}$ by this model is as follows:

$T A_{i, t}=\beta_{0}+\beta_{1} \Delta$ Sales $_{i, t}+\beta_{2} P P E_{i, t}+\beta_{3} \Delta C F O_{i, t}+\varepsilon_{i, t}$

For each year, the residuals are calculated from equation 5 and residuals from equation 5 indicates AEM by the firm. All the variables in equation 5 are scaled by the lag of total as sets to control the possibility of heteroskedasticity. The absolute value of residuals is taken, and the high value shows more earning management.

\section{Audit Quality}

In different studies, audit quality is taken by different measures to check the audit quality of the firm. The audit quality is measured by audit fees charged by the audit firm, the market share of the audit firm, auditor specialization for a particular industry and by big 4 auditors (Francis, 2004). In this study, the big 4 audit firms are taken as a measure for audit quality. Big 4 firms represent high quality of audit (Francis and Krishnan, 1999). The dummy variable will be used if the firm is audited by any of these four audit firms than 1 will be used to tell that audit quality of the firm is high and if any other audit firm is taken that 0 will be used to ascertain that audit quality of the firm is not that good.

Control Variables A set of control variables are also included in model 1, as there are many other factors which are influencing the investment efficiency of the firm. The literature tells us that size, age, the growth opportunities, the financial distress faced by the firm, operating cycle and debt of the firm are taken as control variables.

\section{Result and Discussion}

The earlier literature shows that firm investment efficiency depends on the accounting quality of the firm and firm restricts there overinvestments in settings prone to overinvestment (Biddle et al., 2009). The reason for this reduction in overinvestment and more efficient investments are made by firms. In the case of cash constrained and over debt firms, the firms with excellent investment opportunities forgo good investments due to limited access to new additional funds (García Lara et al., 2016). The other phenomenon which could affect the investment performance of the firm is the audit quality of the firm. It is well documented and researched that proper quality audit by auditors reduces the information asymmetry between managers and shareholders of the firm and it improves the quality of information (Elaoud and Jarboui, 2017, Lenard and Yu, 2012, Bentley et al., 2013). The audit quality also improves the firm investment efficiency and as information content is improved it enhance the confidence of investors which translates into an improvement in the investment efficiency of the firm (Tong and Haresh, 2009).

\subsection{Summary Statistics and Correlation Matrix}

Table 1 of the study presents the descriptive result of the study. Panel A of the table presents the results for the dependent variables of the study. The results show that textile firms in Pakistan are involved in over and underinvestment and mean value shows that there are sub-optimal investments by the textile firms in the country. The next panelB shows the results for AEM measures where we can see that each measure of AEM shows some level of EM by the firms. The next panel of the table shows the result for the control variable. The firms are growing, and distress level is there which need to be investigated further. Table 2 of the study presents the result for Pearson correlation matrix. The results indicate that there is a positive relationship between earning management measures and inefficient investments, so it shows that firms which are involved in EM are making inefficient investments. The result for audit quality shows that audit quality has a negative impact on efficient investments, so we can say better monitoring have a positive impact on investments by the firm. Other variables are also showing some relationship between a different set of variables. The multicollinearity is not an issue as correlation between variables is in acceptable range.

\subsection{Regression Results}

Table 3 presents the result of EM on the over and underinvestment of the firm in the Textile sector of the country. The table is divided into two parts where first three measures of the AEM present the result of the impact of EM on overinvestments by the firm and the second three measures are presenting the result for the impact of EM on underinvestment by the firms. The bottom part of the table shows the model specification results where we can see that $\mathrm{R}$-square value and F-values are presented.

We start the discussion from the impact of AEM on overinvestment by evaluating results for the first three measures of AEM. The independent variable is the measure of AEM and the dependent variable is overinvestments by the firm. The results of three measures of the AEM are suggestive that firms which are doing EM are involved in overinvestments due to 
self-serving behavior of managers. The moral hazard problem exists, and firm managers are hiding the true performance of the firm just for empire building activities (Rowell and Connelly, 2012). The significance level for all the three measures of AEM on overinvestments is at $5 \%$ significance level. Regulators need to check that how they can control AEM of the firm as it is damaging the resources of economy and managers are involved in inefficient investments. The result of the control variables shows that firms with history are making an efficient investment. The audit quality has a positive impact on the investment efficiency of the firms and financial strength also make firm to make efficient investments. From the results, we can observe the H1a of the study.

The impact of AEM on underinvestment shows that the coefficient of AEM for it is positive but not significant. The results are not confirming the hypothesis $\mathrm{H} 1 \mathrm{~b}$ of the study. The results are not confirming the adverse selection impact on the investments by the firm in the context of the textile sector of Pakistan. We can say that more detailed analys is is required for this phenomenon and look for reasons that if sub-optimal investments are only due to overinvestments activities by the firm and there is no underinvestment involved in it. Further study with reliable measures of investment efficiency scores is required to check this phenomenon. The results for other control variables are the same as for the first three measures of the study. The goodness of fit of all the models is quite satisfactory and $\mathrm{F}$ value shows that all models are modeled correctly.

Table 4 of the study shows the results to check how interaction effect of audit quality and EM have its impact on the over and underinvestment activities of the firms in the context of the textile sector of Pakistan. The goodness of fit and model specification shows that all the models for all measures of AEM are correctly specified. Like in table 3 , this table also shows the results in two parts where first 3 measures are for the impact of AEM on overinvestments and other 3 are for the impact of AEM on underinvestment by checking the moderating impact of audit quality on the said relationship.

The results from the first three columns show that EM positively related to overinvestments and firms which are involved in AEM are doing overinvestments. In the same scenario when we see the interaction effect between audit quality and AEM, we see that it has a negative and significant impact on the overinvestment. As we see both the coefficients together, we can see that firms which are audited by good audit firms are having less negative effect of AEM on the investment quality of the firm. This tells us that monitoring the activities of the managers make them discipline and make them to work for the development of the firm. The result confirms that monitoring improves the performance of the firm managers (Jensen, 1994). From the results, we accept the hypothesis H2a of the study. The control variable of the study is showing the same kind of results as we have discussed in table 3 of the study. The result for the next three measures of table 4 shows the impact on underinvestment by the firm due to AEM and joint effect of AEM and audit quality. The results for these measures are not significant, but the signs of the coefficient are quite comparable with the other measures which we have discussed earlier. The results for this measure need to be further investigated so that we can ascertain the reasons for the insignificant results. From the results, we are not in position to accept the hypothes is $\mathrm{H} 2 \mathrm{~b}$ of the study. The results of control variables are quite comparable with the results of overinvestments.

\section{Conclusion}

In this study, we investigated the impact of AEM on the investment performance of the firm with the moderating role of auditor quality. To study this impact, we will take the textile firms which are listed in Pakistan Stock Exchange (PSX). The auditor quality we will be ascertained with the help of auditors if the company is audited by Big4 or not. The literature suggests that as the quality of information goes down it impact negatively on the investment performance of the firm and firms are involved in over and underinvestment. The mechanism of monitoring improves this relationship which is discussed above, so the monitoring role of auditors has a positive impact on the investment performance of the firm.

The result of the study suggests that as managers of the firm are involved in AEM, so these firms are doing more overinvestments and it hurts the investment objective of the firms. It also damages the agency relationship and deterioration in the quality of information leads to sub-optimal investments. Further investigation revealed to us that the monitoring role of audit weakens the relationship which we have discussed earlier and better monitoring discipline the activities of the managers. The results of the study are not significant for the underinvestment behavior of the firms and if EM has its impact on it.

These results contribute to the literature on the role of auditor quality in improving the information asymmetry problem between stakeholders of the firm. The study on auditor role in mitigating information asymmetry and improving investment efficiency of the firm is a scarce topic in corporate finance and by investigating an emerging market of the world, we hope that regulators and researchers will see different aspects of auditing quality to reduce the EM of the firm to improve the investment efficiency. The managers of the firm are involved in different value destroying activities by indulging themselves in EM activities and audit quality can play an active role in monitoring their activities and improve the investment quality of the firm

\section{References}

- Abid, A., Shaique, M. \& Anwar Ul Haq, M. 2018. Do Big Four Auditors Always Provide Higher Audit Quality? Evidence from Pakistan. International Journal of Financial Studies, 6, 58. $\underline{\text { Crossref }}$

- Biddle, G. C., Hilary, G. \& Verdi, R. S. 2009. How does financial reporting quality relate to investment efficiency? 
Journal of Accounting and Economics, 48, 112-131. Crossref

- Bushman, R. \& Smith, A. 2001. Financial accounting information and corporate governance. Journal of Accounting and Economics, 31, 237-333. Crossref

- Cahan S., Godfrey J. \& M., H. J. 2006. Auditor Specialization: The Influence of Investment Opportunities. papers.ssrn.com.

- Chen, F., Hope, O.-K., Li, Q. \& Wang, X. 2011. Financial Reporting Quality and Investment Efficiency of Private Firms in Emerging Markets. The Accounting Review, 86, 1255-1288. Crossref

- Cohen, D. A. \& Zarowin, P. 2008. Economic Consequences of Real and Accrual-Based Earnings Management Activities.

- Cutillas Gomariz, M. F. \& Sánchez Ballesta, J. P. 2014. Financial reporting quality, debt maturity and investment efficiency. Journal of Banking \& Finance, 40, 494-506. Crossref

- Deboskey, D. G. \& Jiang, W. 2012. Earnings management and auditor specialization in the post-sox era: an examination of the banking industry. Journal of Banking \& Finance, 36, 613-623. Crossref

- Dechow, P. M. \& Skinner, D. J. 2000. Earnings management: Reconciling the views of accounting academics, practitioners, and regulators. Accounting Horizons, 14, 235-250. Crossref

- Eisdorfer, A., Giaccotto, C. \& White, R. 2013. Capital structure, executive compensation, and investment efficiency. Journal of Banking \& Finance, 37, 549-562. $\underline{\text { Crossref }}$

- Fazzari, S., Hubbard, M. G. R. \& Peterson, B. C. 1988. Financing Constraints nad Corporate Investment. Brookings Papers on Economic Activity 141-195. Crossref

- Francis, J. \& Krishnan, J. 1999. Accounting accruals and auditor reporting conservatis m. Contemporary Accounting Research, Spring, 135-165. Crossref

- Francis, J. R. 2004. What do we know about audit quality? The British Accounting Review, 36, 345-368. Crossref

- Healy, P. M. \& Wahlen, J. M. 1999. A review of the earnings mamangement literature and its implication for standar setting. Accounting Horizons, 13, 365-383. Crossref

- Houcine, A. 2013. Does Accounting Conservatism Affect firm investment efficiency in an emerging market? evidence from Tunisian context. African Journal of Accounting Audit and Finance, 2, 209-232. Crossref

- Houcine, A. 2017. The effect of financial reporting quality on corporate investment efficiency: Evidence from the Tunisian stock market. Research in International Business and Finance, 42, 321-337. Crossref

- Ilmas, F., Tahir, S., Asrar-Ul-Haq, M. \& Mcmillan, D. 2018. Ownership structure and debt structure as determinants of discretionary accruals: An empirical study of Pakistan. Cogent Economics \& Finance, 6.

- Jere R. Francis \& Wang, D. 2008. The Joint Effect of Investor Protection and Big 4 Audits on Earnings Quality around the World. Contemporary Accounting Research, 25, 157-191. Crossref

- Jones, J. 1991. Earnings management during import relief investigations. Journal of Accounting Research, 29, 193228. $\underline{\text { Crossref }}$
- Kasznik, R. 1999. On the association between voluntary disclosure and earnings management. Journal of Accounting Research, 37, 57-81. Crossref

- Mcnichols, M. F. \& Stubben, S. R. 2008. Does Earnings Management Affect Firms' Investment Decisions? The Accounting Review, 83, 1571-1603. Crossref

- Modigliani, F. \& Miller, M. 1958. The cost of capital, corporation finance and the theory of investment. The American Economic Review, 48, 261-297.

- Myers, S. C. 1984. The Capital Structure Puzzle. Journal of Finance 39, 574-592. $\underline{\text { Crossref }}$

- Newman, D. P., Patterson, E. R. \& Smith, J. R. 2005. The role of auditing in investor protection. The Accounting Review, 80, 289-313. Crossref

- Romanus, R. N., Maher, J. J. \& Fleming, D. M. 2008. Auditor industry specialization, auditor changes, and accounting restatements. Accounting Horizons, 22, 389413. $\underline{\text { Crossref }}$

- SBP 2018. Economic Outlook of Pakistan. In: (SBP), S. B. O. P. (ed.). Karachi: SBP.

- Shen, C.-H., Luo, F. \& Huang, D. 2015. Analysis of earnings management influence on the investment efficiency of listed Chinese companies. Journal of Empirical Finance, 34, 60-78. Crossref

- Stubben, S. R. 2010. Discretionary Revenues as a Measure of Earnings Management. The Accounting Review, 85, 695 717. Crossref

- Worldbank 2018. The World Bank in Pakistan. In: Mariam, A. (ed.). Islamabad: World Bank 


\section{Appendices}

Table 1: Summary Statistics

\begin{tabular}{c|c|c|c|c|c|c}
\hline Variables & $\mathrm{N}$ & Mean & Std. Dev & Median & Max & Min \\
\hline Panel A & & & & & & \\
Overinvest & 144 & 0.102 & 0.192 & 0.057 & 1.052 & 0.0004 \\
UnderInvest & 336 & 0.079 & 0.096 & 0.042 & 0.789 & 0.0007 \\
\hline Panel B & & & & & & \\
AEM Variables & & & & & & \\
DAC & 480 & 0.034 & 0.053 & 0.022 & 0.433 & 0.0002 \\
Kaz & 480 & 0.055 & 0.074 & 0.048 & 0.522 & 0.0001 \\
Agg AEM & 480 & 0.043 & 0.065 & 0.039 & 0.454 & 0.0033 \\
\hline Panel C & & & & & & \\
Control Variables & & & & & & \\
Age & 480 & 3.882 & 0.443 & 3.556 & 4.212 & 1.451 \\
Size & 480 & 16.887 & 1.323 & 16.236 & 19.945 & 13.09 \\
AuQ & 480 & 0.211 & 0.323 & 0.000 & 1.000 & 0.000 \\
Z Score & 480 & 1.453 & 0.717 & 1.033 & 4.322 & 0.244 \\
Growth & 480 & 1.12 & 4.002 & 0.99 & 27.22 & -1.4 \\
Oper Cycle & 480 & 4.778 & 0.564 & 4.232 & 8.331 & 2.217 \\
Leverage & 480 & 0.466 & 0.321 & 0.430 & 0.971 & 0.000 \\
\hline
\end{tabular}

Note: This table illustrates the descriptive statistics for the variables involved in the sample of the study. Panel A of the table contains the dependent variables for the study. The dependent variable for the study is over and under investments which is calculated by sales growth model by Biddle et. al (2009). Panel B of the table shows the independent variables to check the EM activities of the firm. AEM measures are presented in the table. The first measure is from discretionary accrual model, the second is from Kas znik model and last one is aggregate model of AEM. From panel C we can see the descriptive for control variables. Age is the log of years of incorporation of the firm. Size is log of firm assets, AuQ is dummy variable which take the value of 1 if company is audited by Big 4 otherwise it is $0, \mathrm{Z}$ Score is financial strength of the company measure through Altman's (1983) model, Growth is growth opportunities of the firm calculated by market to book value of the equity of the firm. Oper Cycle shows the number of days of inventory plus number of days in receivable and their log to see working capital position of the company. Leverage is total debt to asset ratio.

Table 2: Correlation Matrix

\begin{tabular}{|c|c|c|c|c|c|c|c|c|c|c|c|c|}
\hline Variable & Over & Under & DAC & KAZ & AAEM & Age & Size & $\mathrm{AuQ}$ & $\mathrm{Z}$ & Growth & Oper & Lev \\
\hline Under & 0.42 & & & & & & & & & & & \\
\hline DAC & 0.09 & 0.06 & & & & & & & & & & \\
\hline AAEM & 0.11 & 0.03 & 0.47 & 0.43 & & & & & & & & \\
\hline Age & -0.13 & -0.17 & 0.12 & 0.15 & 0.18 & & & & & & & \\
\hline $\mathrm{AuQ}$ & -0.21 & -0.18 & 0.32 & 0.28 & 0.31 & 0.32 & 0.38 & & & & & \\
\hline $\mathrm{Z}$ & -0.16 & -0.22 & 0.24 & 0.21 & 0.28 & 0.45 & 0.31 & 0.18 & & & & \\
\hline Growth & 0.23 & 0.18 & -0.19 & -0.37 & -0.41 & -0.12 & -0.05 & -0.01 & 0.07 & & & \\
\hline Oper & -0.15 & -0.19 & 0.23 & 0.21 & 0.25 & 0.24 & 0.17 & 0.04 & 0.27 & 0.34 & & \\
\hline Lev & -0.32 & -0.22 & 0.27 & 0.26 & 0.29 & -0.06 & 0.25 & 0.02 & 0.12 & 0.42 & 0.31 & 1 \\
\hline
\end{tabular}


Table 3: Impact of AEM on Over and Underinvestment

\begin{tabular}{|c|c|c|c|c|c|c|}
\hline \multicolumn{7}{|c|}{ Over/Under-Investment } \\
\hline Variable & $\begin{array}{l}(1) \\
\text { DAC }\end{array}$ & $\begin{array}{l}(2) \\
\text { KAZ }\end{array}$ & $\begin{array}{l}\text { (3) } \\
\text { AAEM }\end{array}$ & $\begin{array}{l}(1) \\
\text { DAC }\end{array}$ & $\begin{array}{l}(2) \\
\text { KAZ }\end{array}$ & $\begin{array}{l}\text { (3) } \\
\text { AAEM }\end{array}$ \\
\hline$\overline{\mathrm{DAC}}$ & $\begin{array}{l}0.045^{* *} \\
(0.025)\end{array}$ & & & $\begin{array}{l}0.0087 \\
(0.365)\end{array}$ & & \\
\hline$\overline{\text { KAZ }}$ & & $\begin{array}{l}0.032^{* *} \\
(0.023)\end{array}$ & & & $\begin{array}{l}0.0024 \\
(0.701)\end{array}$ & \\
\hline$\overline{\text { AAEM }}$ & & & $\begin{array}{l}0.055^{* *} \\
(0.038)\end{array}$ & & & $\begin{array}{l}0.0054 \\
(0.229)\end{array}$ \\
\hline Age & $\begin{array}{l}-0.022^{*} \\
(0.09)\end{array}$ & $\begin{array}{l}-0.023^{*} \\
(0.08)\end{array}$ & $\begin{array}{l}-0.021^{*} \\
(0.081)\end{array}$ & $\begin{array}{l}-0.14^{* *} \\
(0.020)\end{array}$ & $\begin{array}{l}-0.16^{* * *} \\
(0.017)\end{array}$ & $\begin{array}{l}-0.208^{* * * *} \\
(0.000)\end{array}$ \\
\hline Size & $\begin{array}{l}0.0279 \\
(0.849)\end{array}$ & $\begin{array}{l}0.0232 \\
(0.842)\end{array}$ & $\begin{array}{l}0.0265 \\
(0.805)\end{array}$ & $\begin{array}{l}0.0153 \\
(0.605)\end{array}$ & $\begin{array}{l}0.0135 \\
(0.530)\end{array}$ & $\begin{array}{l}0.0135 \\
(0.49)\end{array}$ \\
\hline$\overline{A u Q}$ & $\begin{array}{l}-0.012^{* *} \\
(0.023)\end{array}$ & $\begin{array}{l}-0.013^{* *} \\
(0.028)\end{array}$ & $\begin{array}{l}-0.012^{* *} \\
(0.036)\end{array}$ & $\begin{array}{l}-0.023^{*} \\
(0.064)\end{array}$ & $\begin{array}{l}-0.026^{*} \\
(0.053)\end{array}$ & $\begin{array}{l}-0.025^{*} \\
(0.052)\end{array}$ \\
\hline Z Score & $\begin{array}{l}-0.17^{* * * *} \\
(0.000)\end{array}$ & $\begin{array}{l}-0.156^{* * *} \\
(0.000)\end{array}$ & $\begin{array}{l}-0.137^{* * * *} \\
(0.000)\end{array}$ & $\begin{array}{l}-0.0131 \\
(0.338)\end{array}$ & $\begin{array}{l}-0.0121 \\
(0.41)\end{array}$ & $\begin{array}{l}-0.0112 \\
(0.36)\end{array}$ \\
\hline Growth & $\begin{array}{l}0.0000 \\
(0.99)\end{array}$ & $\begin{array}{l}0.0003 \\
(0.92)\end{array}$ & $\begin{array}{l}0.0003 \\
(0.99)\end{array}$ & $\begin{array}{l}0.0006 \\
(0.638)\end{array}$ & $\begin{array}{l}0.0006 \\
(0.66)\end{array}$ & $\begin{array}{l}0.0006 \\
(0.643)\end{array}$ \\
\hline$\overline{\text { OperCyc }}$ & $\begin{array}{l}-0.087^{* * * *} \\
(0.000)\end{array}$ & $\begin{array}{l}-0.09^{* * * *} \\
(0.000)\end{array}$ & $\begin{array}{l}-0.089^{* * * *} \\
(0.000)\end{array}$ & $\begin{array}{l}-0.01 \\
(0.62)\end{array}$ & $\begin{array}{l}-0.006 \\
(0.69)\end{array}$ & $\begin{array}{l}-0.012 \\
(0.64) \\
\end{array}$ \\
\hline Leverage & $\begin{array}{l}-0.12^{*} \\
(0.074)\end{array}$ & $\begin{array}{l}-0.15^{*} \\
(0.077)\end{array}$ & $\begin{array}{l}-0.14^{*} \\
(0.070)\end{array}$ & $\begin{array}{l}-0.05^{* * * *} \\
(0.000)\end{array}$ & $\begin{array}{l}-0.052^{* * * *} \\
(0.000)\end{array}$ & $\begin{array}{l}-0.051^{* * * *} \\
(0.000)\end{array}$ \\
\hline Constant & $\begin{array}{l}0.9231 * * \\
(0.03)\end{array}$ & $\begin{array}{l}0.9012^{* * *} \\
(0.04)\end{array}$ & $\begin{array}{l}0.9213 * * \\
(0.032)\end{array}$ & $\begin{array}{l}0.962^{* *} \\
(0.034)\end{array}$ & $\begin{array}{l}0.962^{* *} \\
(0.043)\end{array}$ & $\begin{array}{l}0.951^{\text {** }} \\
(0.02)\end{array}$ \\
\hline $\begin{array}{l}\text { Fixed Effects } \\
\text { R-Square } \\
\text { F > P }\end{array}$ & $\begin{array}{l}\text { Yes } \\
0.3810 \\
0.0000\end{array}$ & $\begin{array}{l}\text { Yes } \\
0.3791 \\
0.0000\end{array}$ & $\begin{array}{l}\text { Yes } \\
0.3943 \\
0.0000\end{array}$ & $\begin{array}{l}\text { Yes } \\
0.3021 \\
0.0000\end{array}$ & $\begin{array}{l}\text { Yes } \\
0.2954 \\
0.0000\end{array}$ & $\begin{array}{l}\text { Yes } \\
0.3122 \\
0.0000\end{array}$ \\
\hline
\end{tabular}

Table 4: Moderating Impact of Audit Quality on Relationship between AEM and Over and Underinvestment

\begin{tabular}{|c|c|c|c|c|c|c|}
\hline Variable & $\begin{array}{l}(1) \\
\text { DAC }\end{array}$ & $\begin{array}{l}\text { (2) } \\
\text { KAZ }\end{array}$ & $\begin{array}{l}\text { (3) } \\
\text { AAEM }\end{array}$ & $\begin{array}{l}(1) \\
\text { DAC }\end{array}$ & $\begin{array}{l}(2) \\
\text { KAZ }\end{array}$ & $\begin{array}{l}\text { (3) } \\
\text { AAEM }\end{array}$ \\
\hline DAC & $\begin{array}{l}0.2356^{* *} \\
(0.02)\end{array}$ & & & $\begin{array}{l}0.032 \\
(0.40)\end{array}$ & & \\
\hline KAZ & & $\begin{array}{l}0.2563 * * \\
(0.012)\end{array}$ & & & \begin{tabular}{|l|}
0.034 \\
$(0.36)$
\end{tabular} & \\
\hline $\begin{array}{l}\text { AAEM } \\
\text { AEM*AuQ }\end{array}$ & $\begin{array}{l}-0.1342^{*} \\
(0.067)\end{array}$ & $\begin{array}{l}-0.1523^{*} \\
(0.054)\end{array}$ & $\begin{array}{l}0.2413^{* * *} \\
(0.021) \\
0.142^{*} \\
(0.061)\end{array}$ & $\begin{array}{l}-0.25 \\
(0.61)\end{array}$ & \begin{tabular}{|l}
-0.23 \\
$(0.53)$
\end{tabular} & $\begin{array}{l}0.047 \\
(0.31) \\
-0.27 \\
(0.45)\end{array}$ \\
\hline Age & $\begin{array}{l}-0.77^{*} \\
(0.061)\end{array}$ & $\begin{array}{l}-0.67^{*} \\
(0.05)\end{array}$ & $\begin{array}{l}-0.74^{*} \\
(0.058)\end{array}$ & $\begin{array}{l}-0.52^{* *} \\
(0.04)\end{array}$ & $\begin{array}{l}-0.54^{* *} \\
(0.043)\end{array}$ & $\begin{array}{l}-0.70^{* *} \\
(0.014)\end{array}$ \\
\hline$\overline{\text { Size }}$ & $\begin{array}{l}l^{0.0523^{* * *}} \\
(0.03)\end{array}$ & $\begin{array}{l}0.0592^{* *} \\
(0.01)\end{array}$ & 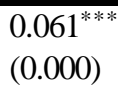 & $\begin{array}{l}0.1250 \\
(0.363)\end{array}$ & \begin{tabular}{|l|}
0.183 \\
$(0.33)$
\end{tabular} & $\begin{array}{l}0.138 \\
(0.45)\end{array}$ \\
\hline $\mathrm{AuQ}$ & $\begin{array}{l}-0.024^{*} \\
(0.075)\end{array}$ & $\begin{array}{l}-0.027 * \\
(0.07)\end{array}$ & $\begin{array}{l}-0.026^{*} \\
(0.072)\end{array}$ & $\begin{array}{l}-0.0209^{*} \\
(0.066)\end{array}$ & \begin{tabular}{|l}
$-0.0211^{*}$ \\
$(0.054)$
\end{tabular} & $\begin{array}{l}-0.0221 \\
(0.05)\end{array}$ \\
\hline
\end{tabular}




\begin{tabular}{|c|c|c|c|c|c|c|}
\hline Z Score & $\begin{array}{l}0.0221^{*} \\
(0.059)\end{array}$ & $\begin{array}{l}-0.0247 * * \\
(0.045)\end{array}$ & $\begin{array}{l}-0.0245^{\text {** }} \\
(0.047)\end{array}$ & $\begin{array}{l}-0.062^{* * *} \\
(0.000)\end{array}$ & $\begin{array}{l}-0.066^{* * *} \\
(0.000)\end{array}$ & $\begin{array}{l}-0.069^{* * *} \\
(0.000)\end{array}$ \\
\hline Growth & $\begin{array}{l}-0.001 \\
(0.381)\end{array}$ & $\begin{array}{l}-0.0013 \\
(0.31)\end{array}$ & $\begin{array}{l}-0.0014 \\
(0.27)\end{array}$ & $\begin{array}{l}0.0005 \\
(0.67)\end{array}$ & $\begin{array}{l}0.0005 \\
(0.68)\end{array}$ & $\begin{array}{l}0.0004 \\
(0.73)\end{array}$ \\
\hline OperCyc & $\begin{array}{l}0.0243 * \\
(0.051)\end{array}$ & $\begin{array}{l}-0.0253 * * \\
(0.47)\end{array}$ & $\begin{array}{l}-0.0266 * * \\
(0.031)\end{array}$ & $\begin{array}{l}-0.057^{* * *} \\
(0.000)\end{array}$ & $\begin{array}{l}-0.059^{* * *} \\
(0.000)\end{array}$ & $\begin{array}{l}-0.067^{* * * *} \\
(0.000)\end{array}$ \\
\hline Leverage & $\begin{array}{l}-0.029^{*} \\
(0.099)\end{array}$ & $\begin{array}{l}-0.12^{* *} \\
(0.035)\end{array}$ & $\begin{array}{l}-0.044 * * \\
(0.085)\end{array}$ & $\begin{array}{l}-0.079^{* *} \\
(0.018)\end{array}$ & $\begin{array}{l}-0.077^{* *} \\
(0.028)\end{array}$ & $\begin{array}{l}-0.079^{* *} \\
(0.018)\end{array}$ \\
\hline Constant & $\begin{array}{l}0.961 * * \\
(0.023)\end{array}$ & $\begin{array}{l}0.951 * * \\
(0.032)\end{array}$ & $\begin{array}{l}0.956^{* * *} \\
(0.030)\end{array}$ & $\begin{array}{l}0.901^{*} \\
(0.06)\end{array}$ & $\begin{array}{l}0.911 * * \\
(0.042)\end{array}$ & $\begin{array}{l}0.932 * * \\
(0.034)\end{array}$ \\
\hline $\begin{array}{l}\text { Fixed Effects } \\
\text { R-Square } \\
\text { F > P Value }\end{array}$ & $\begin{array}{l}\text { Yes } \\
0.4412 \\
0.0000\end{array}$ & $\begin{array}{l}\text { Yes } \\
0.4662 \\
0.0000\end{array}$ & $\begin{array}{l}\text { Yes } \\
0.4533 \\
0.0000\end{array}$ & $\begin{array}{l}\text { Yes } \\
0.3212 \\
0.0000\end{array}$ & $\begin{array}{l}\text { Yes } \\
0.3201 \\
0.0000\end{array}$ & $\begin{array}{l}\text { Yes } \\
0.3341 \\
0.0000\end{array}$ \\
\hline
\end{tabular}

